12th LUMEN International Scientific Conference Rethinking Social Action. Core Values in Practice | RSACVP 2019 | 15-17 May 2019 | lasi - Romania

\title{
The Successional Indignity in the New Romanian Civil Code (Law No. 287/2009): Conceptual Premises and Practical Perspectives
}

\author{
Mirela Carmen DOBRILA
}

https://doi.org/10.18662/lumproc.155

How to cite: Dobrilă, M.C. (2019). The Successional Indignity in the New Romanian Civil Code (Law No. 287/2009): Conceptual Premises and Practical Perspectives. In C. Ignatescu (ed.), 12th LUMEN International Scientific Conference Rethinking Social Action. Core Values in Practice, 15-17 May 2019, Iasi - Romania (pp. 74-81). Iasi, Romania: LUMEN Proceedings. https://doi.org/10.18662/lumproc. 155 


\title{
The Successional Indignity in the New Romanian Civil Code (Law No. 287/2009): Conceptual Premises and Practical Perspectives
}

\author{
Mirela Carmen DOBRILĂ ${ }^{1 *}$
}

\begin{abstract}
The new Romanian Civil Code changes the previous perspective of the institution of successional indignity, which was applicable, as a requirements in order to be able to inherit, only in cases of intestacy (ab intestat succession). In the New Civil Code (articles 958-961), successional indignity becomes a general condition for inheritance, applicable to both in cases of intestacy as well as in cases of succession by will. The institution of indignity bas the effect of depriving the successor of the right to receive a determined succession belonging to a person to whom he has become undignified by committing serious actions, as limited by the legal norm.

The article analyzes the particularities of the successional indignity and the New Civil Code unitary regulation of the indignity pertaining to legal heirs, and that applicable to successors by will. The article analyzes both the particularities of de jure indignity (ope legis, Article 958 of the New Civil Code) and the particularities of the judicial indignity, declared by the court of law (Article 959 of the New Civil Code), as well as the effects of inheritance. The article analyzes the possibility of removing the effects of indignity and the conditions for pardoning the undignified heir, with new implications regulated in Article 961 of the New Civil Code.
\end{abstract}

Keywords: successional indignity; Law no. 287/2009; New Romanian Civil Code; Romanian succession law; the right to inherit; de jure and judicial indignity.

\section{A different vision in the New Civil Code: succesional indignity, general condition of the right to inheritance}

The New Romanian Civil Code - Law No. 287/2009 [1], which has as its main source of inspiration the Civil Code of Quebec, regulates the successional indignity in the chapter on general conditions of the right to inherit, more exactly in Articles 958-961. The regulation of the successional

1 Lecturer PhD, Faculty of Law, University „Alexandru Ioan Cuza” Iaşi, România, mirela.dobrila@gmail.com. 
indignity in the New Civil Code addresses certain changes: the introduction of judicial indignity, changes in the case of de jure indignity, changes in the effects (indignity operates for both the legal inheritance and for the testamentary inheritance, the descendants of the undignified may come to inheritance by representing the undignified, even if he is alive, the particular effect of the succession representation concerning the special obligation of report), the elimination of the effects of the successional indignity acknowledged as novelty.

Both in the New Civil Code and the Civil Code of 1864, the successional indignity retains the same meaning in the sense that the person committing serious deeds to the deceased will not have the right to come to the latter's inheritance.

The justification of the existence of the institution of successional indignity is based on the idea that it would be unfair and immoral that the person who murdered de cuius to be the one who inherits him, with the argument that no one can open his way to an inheritance through murder. Regarding the petition on the unconstitutionality of the de jure indignity, the Constitutional Court Decision no. 530/2005 [2] states in its content that the perpetrator of a murder offense cannot claim a legal status equal to that of other citizens because he self-excluded from this group with his own deed and his indignity is not contrary to the provisions of the Constitution.

Regarding the application of the law over time, it should be noted that the Article 93 of Law no. 71/3 June 2011 regarding the implementation of the New Civil Code [3], states that the provisions on indignity de jure (Article 958 of the New Civil Code) and judicial indignity (Article $959 \mathrm{New}$ Civil Code) applies only to acts committed after the enforcement of the Civil Code.

\section{De jure indignity: the introduction of the possibility of operating indignity if the deeds were determined by a final court judgment. Invoking its own indignity}

Indignity occurs by law in certain assumptions expressly indicated in Article 958 New Civil Code: "a) the person convicted of a criminal offense with the intention of killing the person who leaves the inheritance"; b) "the person convicted - before the opening of the inheritance - for committing an offense with the intention of killing another potential heir" (general vocation to the same succession), "which, if the inheritance procedures opened at the date of the offence, it would have removed or would have restrict the vocation to the inheritance of the offender". 
There is no need for a judgment that should determine that the de jure indignity is involved, but if litigations arise regarding the fulfillment of the conditions required for indignity, the court will rule on the fulfillment of the conditions, that is to say, the court determines the indignity which has operated ope legis since the opening of the inheritance. The action for determining successional indignity may be filed after the inheritance is opened and can only be received if the undignified has a concrete legal vocation to the succession [4], [5].

For there to be a successional indignity, a certain offense is necessary to be determined and the act to be committed with the intention of killing; the attempt is assimilated to the consumed offense. As for the complex criminal participation, the interpretation will be according to the model of the French Civil Code, ie all participants will be undignified [5], [6]. Thus, Article $958 \mathrm{New}$ Civil Code refers to crimes such as: murder - Article 188 of the Law no. 286/2009- the New Criminal Code of 17 July 2009, published in the Official Gazette of Romania no. 510 of 24 July 2009), aggravated murder - Article 189 New Criminal Code, killing upon the victim's request - Article 190 New Criminal Code [5], which should not be confused with the crime of determining or facilitating suicide (Article 191 of the New Criminal Code for which the judicial indignity is questioned) (the opinion according to which it's not necessary for the de jure indignity to operate is questionable [7], as it is considered sufficient to rule criminal liability, so as to exclude an excess of punishments), the killing of the newborn by the mother Article 200 of the New Criminal Code; offenses committed by fault are excluded (manslaughter under Article 192 of the New Criminal Code) or premeditate (battery and bodily harm causing death in Article 195 of the New Criminal Code).

De jure indignity requires the fulfillment of the condition for the existence of a criminal conviction. As a novelty, ,if the conviction for the deeds of indignity is hindered by the death of the perpetrator, by amnesty or by the prescription of criminal liability, indignity operates if those facts have been established by a final civil judicial decision" (article 958 para. 2 New Civil Code). The introduction of this possibility is justified by the principles established by the European Court of Human Rights in the case of Velcea and Mazăre v. Romania [8], [9].

We consider as being wrong the judgment by which the civil court admitted an action in declaring indignity: the applicant's father committed the crime of murder to the applicant's mother found in Article $188 \mathrm{New}$ Criminal Code (hammer hitting and hanging) and then committed suicide by hanging (classification of the file on the ground that death is a cause that prevents the commencement and the exercising of prosecution, Article 16 
letter $\mathrm{f}$ of the New Criminal Procedure Code); the court declared the indignity of the surviving spouse (Article 959 paragraph 4 of the New Criminal Code - judicial indignity), although it is a case of de jure indignity based on a conviction, and when there is no criminal judgment, indignity will operate de jure if the civil court pronounces a judgment establishing the undignified deeds [10].

Regarding the possibility of an undignified heir to invoke its own indignity, a distinction must be made between the successional de jure indignity within the Civil Code of 1864 and the New Civil Code, which introduces, besides the de jure indignity (as civil sanction) [11], the judicial indignity (as civil punishment). By principle, the undignified heir may appeal to the successional de jure indignity as it operates under the law and is not about the invocation of his/her own turpitude; still he cannot rely on judicial indignity because we may consider it to be in breach of the Nemo auditur propriam turpitudinem allegans principle. However, there are certain reservations about the fact that the undignified is a successor who can give up the inheritance; there are situations in which there is a moral conflict, in the sense that the undignified takes upon himself that he committed the act of indignity and does not want to be a heir; there are also reservations even about invoking his own turpitude.

\section{Judiciary indignity. Introducing the possibility of declaring judicial indignity if the facts were determined by a final civil court ruling - a single action}

The judicial indignity, regulated as a new institution in Article 959 The New Civil Code intervenes (the wording of the code being questionable - "indignity may be declared") for:

- committing, intentionally, against the victim of serious acts of violence, physical or moral violence (battery and other acts of violence, Article 193 of New Criminal Code, bodily harm - Article 194 New Criminal Code but not the harm by fault, domestic violence Article 199 New Criminal Code, with reference to the deeds from of Article 194 and 195 New Criminal Code committed against a family member, the harm to the newly born baby - Article 202, paragraphs 2-4 New Criminal Code, the rape Article 218 paragraph 1-3 New Criminal Code, sexual assault - Article 219 paragraph 1, 2 New Criminal Code, respectively the threat - Article 206 New Criminal Code, blackmail - Article 207, illegitimate deprivation of liberty Article 205), or acts which result in his death, but the author does not act with the intention of killing (the rape that had as a result the death of the 
victim, Article 218 paragraph 4 New Criminal Code, battery and bodily harm causing death - Article 195 New Criminal Code, the robbery that resulted in the death of the victim) - Article 959 para. 1 letter a New Criminal Code. Therefore a conviction judgment by the criminal court is required. It is interesting to highlight a recent judgment of the courts of law who considered that there is indignity for family abandonment which is regarded as a serious moral offense [12].

- ,the act of the person who, willingly, hid, altered, destroyed or falsified the deceased's will" - according to Article 959 para. 1 letter b New Criminal Code; the change of the will of de cuius may occur before or after the inheritance is opened, without the knowledge of de cuius, in bad faith, it does not matter if he destroys a simple project of testament or a void testament.

- the deed of the person who, through dowry or violence, has prevented the person who leaves the inheritance from making, amending or revoking the will - Article 959 para. 1 letter c New Civil Code (a vitiation of the testator's consent).

As a new direction, the New Civil Code (as in the case of de jure indignity) introduces in Article 959 para. (4) the possibility that indignity deeds can be settled by a final civil judicial decision ,, when the conviction for the undignified deeds is hindered by the death of the author, by amnesty or by the prescription of criminal liability"; in this case, judicial indignity may be established based on a judgment given by the civil court. There are not two civil judgments, one for the finding of the deed of indignity and one for declaring indignity, but a single action with two heads of claim (there would also be problems with the one-year time limit) [5]. The term for the action claiming indignity (the introduction of the action means the acceptance of the inheritance) is 1 year, this being a time limit - article 959 New Civil Code (upon the judicial revocation of legacies Article 1069 New Civil Code, the 1 year term is a limitation period).

\section{Effects of successional indignity. Removing the effects of successional indignity. Representation of the undignified}

As effects of indignity (Article 960 of the New Civil Code), the undignified is removed, retroactively, from both the legal and the testamentary inheritance, this representing a denial of the right to inheritance due to an incorrect behavior towards de cuius: the undignified does not take possession of the goods or he has to return (restitution in kind - Article 1639 of the New Civil Code or by equivalent - Article 1641, Article 1642, Article 
1643 of the New Civil Code), with the fruit perceived or the ones he omitted to perceive. The exercised possession on the assets by the undignified is considered to be possession in bad faith.

For the legatee, both indignity and the judicial revocation of legacies for the ingratitude may operate - Article 1069 New Civil Code (the judicial revocation of donations for ingratitude may also operate - Article $1023 \mathrm{New}$ Civil Code), if there are common causes.

Unlike Article 658 of the Civil Code from 1864, which did not allow the descendants of the undignified to come by representation to the inheritance of de cuius, but only in their own name, the New Civil Code marks an important evolution by the fact that indignity, as a strictly personal penalty, does not produce effects on the offender's descendants, who may come to the inheritance by representing the undignified, even if he is alive at the date of the inheritance procedure opening (Article 967 of the New Civil Code). There is a special obligation of report, as a particular effect of succession representation (Article 969 of the New Civil Code): the children of the undignified conceived before the opening of inheritance from which the undignified was excluded (in concert with other children conceived after the inheritance was opened) will report to the inheritance of the undignified the goods received by representing the undignified.

As regards the effects of indignity with third parties, the principle „resoluto iure dantis, resolvitur ius accipientis” applies. For the conclusion of an act with a non-domino, the principle ,nemo plus iuris ad alium transfere potest quam ipse babet" applies. The conservation and management acts concluded between the undignified and third parties are valid insofar as they are beneficial for the heirs. The onerous acts of disposition concluded between the undignified and the third-party acquirers of goodwill are maintained, but the rules of the land book are applicable (for the principle of error communis facit jus/the theory of the apparent inheritor, the requirement of the private act and the invincible and common error no longer appear [11].

As novelty, express forgiveness of the undignified is allowed (indignity being considered a presumed disinheritance [9]), according to Article 961 New Civil Code (tacit forgiveness is not allowed!), as a purely personal and solemn act, expressly by will or through a notarial act by the person who leaves the inheritance (according to Article 95 of Law 71/2011, registration is required in the National Notarial Register provided under Article 1046 New Civil Code). Without an express statement, the legacy left to the undignified after committing the deed that triggers indignity is not considered elimination of the effects. However, we consider [13] that the legacy left to the undignified after committing the act triggering indignity, should produce its effects, because we must take into account the will of the 
de cuins, without considering it forgiveness (tacit forgiveness shall not be admitted) and without removing the effects of indignity.

\section{Conclusions}

The New Romanian Civil Code marks an evolution [14], by adapting the legislative framework: indignity can be either de jure or judicial, it operates for both legal and testamentary inheritance, the descendants of the undignified can come to inheritance by successional representation of the undignified; there is a particular effect of representation - a special obligation of report; it is acknowledged the possibility that indignity can operate lawfully or be declared (if there is no criminal conviction) based on a judgment given by the civil court by which establish the deeds of indignity are found; it is acknowledged the possibility of removing the effects of the indignity, in order to respect the will of de cuius.

\section{References}

[1] Law no. 287/2009 on New Civil Code, published in the Official Gazette of Romania no. 511 of 24 July 2009, as amended by Law no. 71/2011 and rectified in the Official Gazette of Romania no. 427 of 17 June 2011 and in the Official Gazette of Romania no. 489 of 8 July 2011. Law no. 287/2009 published in the Official Gazette of Romania no. 505 of 15 July 2011 (pursuant to Article 218 of Law no. 71/2011 for the enforcement of Law no. 287/2009 on Civil Code, published in the Official Gazette of Romania no. 409 of 10 June 2011) and rectified in the Official Gazette of Romania no. 246 of 29 April 2013.

[2] Decision No. 530/2005 of the Constitutional Court published in the Official Gazette of Romania no. 1040 of 23 november 2005.

[3] Law no. 71 of 3 June 2011 for the implementation of the New Civil Code Law no. 287/2009 on the New Civil Code, published in the Official Gazette no. 409 of 10 June 2011

[4] Malaurie P, Aynés L. Les Successions, Les Libéralités. 4e édition. Paris: Defrénois; 2008. p. 45-47.

[5] Macovei C, Dobrilă MC. Condițiile generale ale dreptului de a moşteni. In: Baias FA., Chelaru E, Constantinovici R, Macovei I, eds. Noul Cod civil. Comentariu pe articole. Bucharest: Publisher C.H. Beck; 2012. p. 1073-1081.

[6] Terré F., Lequette Y. Droit civil. Les successions. Les libéralités. 3rd Edition. Paris: Dalloz; 1997. p. 44-52.

[7] Murariu S. Nedemnitatea succesorală raportată la infracțiunea de ucidere la cererea victimei [Internet]. 2015. Available from: 
https://www.juridice.ro/396336/nedemnitatea-succesorala-raportata-lainfractiunea-de-ucidere-la-cererea-victimei.html.

[8] The European Court of Human Rights. Velcea and Mazăre v. Romania, no. 64301/01, from 01.12.2009, def. at 01.03.2010. Official Gazette of Romania no. 373 of 07/06/2010. Available at: www.scj.ro.

[9] Bob MD. Probleme de moșteniri în vechiul și în Noul Cod civil. Bucharest: Universul Juridic; 2012. p. 101-112.

[10] Court of Sighişoara. Civil sentence no. 416/2019. Available at: www.rolii.ro.

[11] Deak F. Tratat de drept succesoral. 2nd edition. Bucharest: Universul Juridic; 2002. p. 59-73.

[12] Court of Constanța. Civil sentence no. 389/2019.

[13] Dobrilă MC. Iertarea nedemnului: expresă, tacită sau recunoaşterea unui drept de a culege legatul lăsat de către testator printr-un testament întocmit după săvârşirea faptei de nedemnitate succesorală?. Journal Dreptul. 2018; 63-73.

[14] Macovei C, Dobrilă MC. The New Institution of Indignity in Romanian Inheritance Law. In Sandu A, Caras A, eds. International Scientific Conference Tradition and Reform. Social Reconstruction of Europe, 2013. Bologna, Italy: MEDIMOND International Proceedings- Monduzzi Editore International Proceedings Division. 2013. 233-236. 